\title{
DE ANIMA I E II: O MOVIMENTO NOS ÂMBITOS VEGETATIVO E SENSITIVo
}

\author{
[DE ANIMA I AND II: MOVEMENT IN THE VEGETATIVE AND SENSITIVE AMBITS]
}

André Alonso *

Universidade Federal Fluminense/Univ. Fed. do Rio de Janeiro, Brasil

\begin{abstract}
Resumo: O movimento é um conceito essencial na física de Aristóteles e é largamente empregado para explicar as mudanças no mundo sublunar. Ele é investigado, de modo particular, na Física e, como conceito, depende intrinsecamente de noções como ato e potência. No presente artigo, concentro-me, em primeiro lugar, na teoria do movimento que se encontra em Física III e V, em seguida, analiso os modos como ela é utilizada para definir a própria alma e para explicar os diferentes fenômenos vitais - atividades vegetativas e sensitivas - descritos em De Anima I e II.
\end{abstract}

Palavras-chave: Aristóteles; De Anima; movimento
ABSTRACT: Movement is a key concept in Aristotle's physics and is largely used to explain changes in the sublunary sphere. It is especially investigated in the Physics and, as a concept, depends intrinsically on notions like actuality and potentiality. In this paper, I focus first on the theory of movement found in Physics III and V, then I analyze the ways it is used to define the soul itself and to explain the different vital phenomena - vegetative and sensitive activities - described in De Anima I and II.

KEYWORDS: Aristotle; De Anima; movement

\section{INTRODUÇÃO}

$\mathrm{O}$ conceito de movimento é examinado por Aristóteles mais detalhadamente em sua Física, já que é uma noção essencial para explicar as mudanças que ocorrem no seio da realidade sublunar. O movimento abarca fenômenos outros para além da simples transmutação local e com ele se podem explicar não apenas as mudanças que sofrem os entes inanimados, mas também a complexa dinâmica dos seres vivos. Nosso objetivo é analisar como o movimento é utilizado para a compreensão de atividades dos seres animados. Para tal, vamos concentrar-nos nos livros I e II do De Anima de Aristóteles. Como não examinaremos o livro III, o movimento local não será aprofundado, já que é nos capítulos 9 a 11 deste livro que Aristóteles trata do tema.

Primeiramente, trataremos da inserção do De Anima no domínio da física aristotélica e, consequentemente, do conceito de movimento desenvolvido na Física. Em seguida, veremos como este conceito aparece ligado a diferentes atividades nutritivas e sensitivas do vivente.

* Doutor em Filosofia pela Universidade de Louvain. Professor de Grego da Universidade Federal Fluminense e Professor de Filosofia do Programa de Pós-Graduação em Filosofia da Universidade Federal do Rio de Janeiro PPGF/UFRJ.E-mail: andre.alonso@gmail.com 


\section{O DE ANIMA E A DOUTRINA DO MOVIMENTO NA FíSICA}

O De Anima pode-se dividir, em um plano geral, em duas grandes partes, sendo a primeira uma inquirição sobre as principais teorias previamente desenvolvidas sobre a alma, enquanto a segunda constitui um esforço pessoal do autor para desenvolver sua própria especulação sobre o tema. A essa divisão mais geral, sobrepõe-se a tradicional repartição da obra em três livros. $\mathrm{O}$ primeiro deles corresponderia à primeira parte, compreendendo, portanto, a doxografia e a consequente crítica às opiniões elencadas. À segunda parte correspondem o segundo e o terceiro $\operatorname{livros}^{1}$, nos quais se desenvolve uma pletora de tópicos: uma primeira definição de alma, suas faculdades e respectivos objetos, o número dos sentidos, a representação ou imaginação ( $\varphi \alpha v \tau \alpha \sigma i ́ \alpha)$, o intelecto, o movimento local.

No pequeno tratado que é o De Anima, no qual Aristóteles desenvolve um texto conciso sobre um tão vasto assunto, o problema do movimento local tem uma abordagem bastante restrita, mas os termos ligados à noção de movimento consubstanciada no radical кıv- ocorrem mais de trezentas vezes, espalhando-se ao logo de todo o opúsculo, empregando-se nas diferentes partes que tratam de objetos outros que o movimento local propriamente dito. Essa espécie de onipresença da noção de movimento poderia, à primeira vista, causar estranheza a quem atentasse exclusivamente à dimensão, por assim dizer, interna do De Anima, ou seja, considerando-o isolado do restante do corpus aristotelicum, e que pretendesse reduzir a questão do movimento apenas à moção local. $\mathrm{O}$ De Anima, no entanto, não é um tratado independente. A "psicologia" aristotélica insere-se antes no âmbito maior da "física" ou filosofia da natureza, dependendo, portanto, dos princípios mais gerais estabelecidos nessa ciência. Averróis (séc. XII d.C.), no proêmio de seu grande comentário à Física, afirma que esta é a obra que Aristóteles pôs em primeiro lugar no âmbito da "ciência da natureza" (in scientia naturali). A razão disso é que as realidades naturais (res naturales) se dividem conforme as diversas naturezas e, ainda que difiram no que é próprio a cada uma delas, convergem naquelas coisas comuns que nelas existem. A reflexão dessa ciência (ars) que é a física, é, portanto, bipartida, pois há uma parte que se dedica a estudar as coisas comuns a todas as realidades naturais, e essa seria a parte geral, na qual se investigam os princípios de toda a natureza, e há uma outra que examina as coisas que são próprias a cada um dos diferentes gêneros em que se distribuem as realidades naturais. "E essa segunda parte divide-se conforme o número dos diversos gêneros e por isso se puseram vários livros nessa ciência (in hac arte), assim como ocorre na lógica e nas outras ciências especulativas."

Sto. Tomás de Aquino, no comentário à Física, divide os seres em³:

(a) aqueles cujo ser depende da matéria e que não se podem definir sem a matéria;

(b) aqueles que não podem existir sem a matéria sensível, mas em cuja definição não entra a matéria sensível;

(c) aqueles que não dependem da matéria nem quanto ao ser nem quanto à noção.

A metafísica ocupa-se desse último tipo de ser (c), enquanto a matemática se interessa pelos seres que, embora dependam da matéria para existir, não dependem dela para serem definidos (b). Já a filosofia da natureza, que os gregos chamam física, dedica-se aos seres que dependem da matéria sensível tanto em sua existência quanto 
em sua definição $(a)^{4}$.

E quanto ao objeto da física, Sto. Tomás conclui:

E porque tudo que tem matéria é móvel, segue-se que o ente móvel é o objeto da filosofia da natureza. Com efeito, a filosofia da natureza trata dos seres naturais. São naturais aqueles seres cujo princípio é a natureza. Mas a natureza é o princípio do movimento e do repouso naquilo em que ela está. A ciência natural, portanto, trata daqueles seres que têm em si o princípio do movimento. ${ }^{5}$

A física trata, assim, dos princípios gerais do ser móvel, cujo movimento tem sua origem na natureza. Seguem-se a essa obra uma série de outros tratados que têm como objeto as diferentes espécies de seres móveis, sejam estes inanimados, sejam animados. Estes últimos serão examinados justamente no De Anima, que constitui, por conseguinte, uma parte específica do domínio da física antiga ${ }^{6}$.

O livro I da Física é dedicado a investigar o objeto e o método dessa parte da filosofia e Aristóteles introduz, desde o princípio, três conceitos essenciais ao

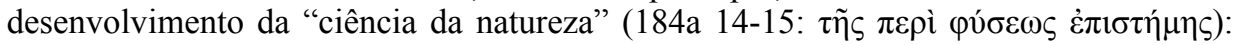

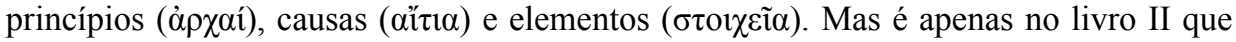
ele abordará o problema da natureza. E nas primeiras linhas apresenta uma divisão geral dos seres em dois grandes grupos:

Dos seres, alguns são por natureza, outros por outras causas; por natureza são os
animais e suas partes, as plantas e, dentre os corpos, os simples, como a terra, o
fogo, o ar e a água (com efeito, dizemos que essas e outras coisas semelhantes são
por natureza). Todas essas coisas claramente se diferenciam das que não estão
constituídas por natureza, pois cada uma delas tem em si um princípio de
movimento e de estabilidade, umas quanto ao lugar, outras quanto ao aumento e à
diminuição, outras quanto à alteração. (as traduções são todas nossas)

Há os seres que são por natureza e os seres que são por outras causas e que não estão constituídos por natureza. Estes últimos seriam oriundos sobretudo da arte

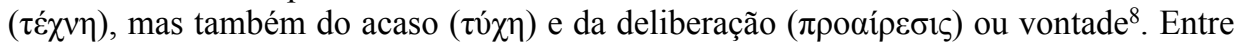
os seres naturais, Aristóteles lista especificamente os animais (e suas partes), as plantas e os quatro elementos. Nessa passagem, ele não menciona nenhum exemplo de seres não naturais, mas na frase seguinte ele o faz, citando uma cama ou um manto, que são

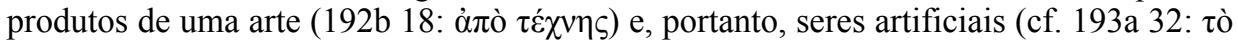
$\tau \varepsilon \chi v ı$ เóv). A diferença entre as coisas naturais e as artificiais reside no fato de que as

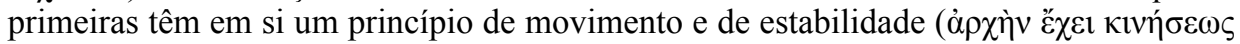

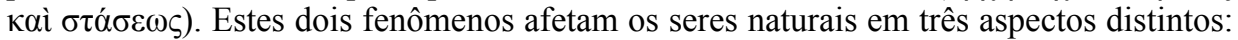

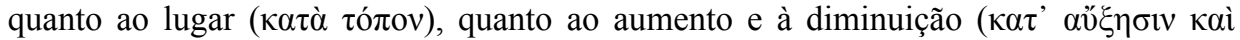

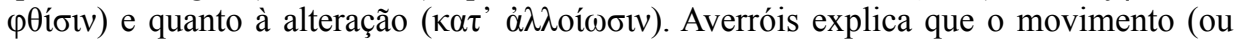
estabilidade) quanto ao lugar refere-se ao movimento local e afeta os quatro elementos, os seres animados e os corpos celestes; o aumento e a diminuição referem-se à transmutação própria aos vegetais (e que existe também nos animais, na medida em que sua alma tem funções vegetativas); a alteração (transmutatio), por sua vez, pode atingir a substância, e teríamos, então, a geração e a corrupção, ou a qualidade, o que constituiria uma simples alteração ${ }^{9}$.

A natureza é, portanto, definida como um princípio ou mesmo uma causa do movimento e do repouso: "[...] porque a natureza é, naquilo a que pertence primeiramente por si e não por acidente, um princípio e uma causa do mover-se e do estar em repouso"10. Aristóteles não prova a existência da natureza, o que, de resto, seria uma tentativa ridícula (193a 3: $\gamma \varepsilon \lambda$ oĩov). A existência da natureza pode ser constatada pela observação dos diferentes entes que possuem as características de 
movimento por ele elencadas. A definição de natureza remete intrinsecamente ao movimento (ou a sua ausência). Por isso, tratará de examinar esse conceito no livro III. E já no início deste, ele retoma a conexão de natureza e movimento e afirma a premência de estudar este último (200b 12-15):

Visto que a natureza é princípio de movimento e de mudança, e que nossa investigação trata da natureza, é preciso que não escape à nossa atenção o que é o movimento, pois, se este for ignorado, é necessário que também se ignore a natureza. ${ }^{11}$

Para entender o que é a natureza, é preciso compreender em que consiste o movimento. Note-se que Aristóteles, no livro II, falava em movimento e estabilidade

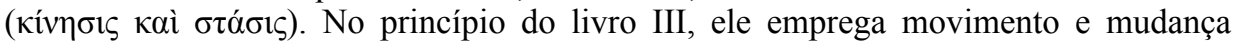

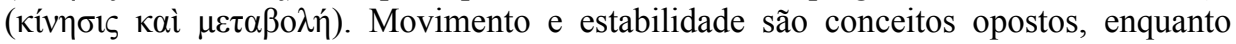
movimento e mudança podem ser tomados como sinônimos.

Antes de tentar definir o movimento, Aristóteles apresenta como preâmbulo a correlação de ato e potência com as categorias. Diz ele: "É possível algo ser apenas em

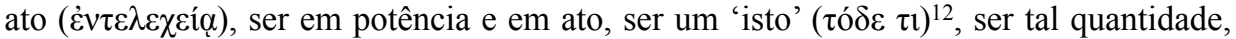
tal qualidade e, de modo semelhante, quanto às outras categorias do ser." $13 \mathrm{O}$ ser dividese em ato e potência e esses se encontram em qualquer das dez categorias. Por isso, além de enumerar explicitamente a substância ( $\tau$ ó $\delta \varepsilon \tau \imath$ ), a quantidade e a qualidade, ele acrescenta "outras categorias do ser". Segundo Averróis, ele menciona a divisão em dez categorias porque quer mostrar que o movimento ocorre apenas em quatro das dez ${ }^{14}$. A introdução das noções de ato e potência dá-se pelo fato de que a definição de movimento dependerá intrinsecamente delas, já que o ato e a potência são naturalmente anteriores ao movimento ${ }^{15}$. E por isso, na sequência, Aristóteles assim define o movimento:

Visto que se distinguiu, em cada gênero, o que está em ato e o que está em potência, o movimento é o ato ( $\dot{\varepsilon} v \tau \varepsilon \lambda \dot{\varepsilon} \chi \varepsilon 1 \alpha)$ do que está em potência enquanto tal, por exemplo, a alteração o é do alterável enquanto alterável, o aumento e a diminuição o são do aumentável e de seu oposto, o diminuível (pois não há nenhum nome comum a ambos), a geração e a corrupção, do passível de ser gerado e do corruptível, o deslocamento, do deslocável. ${ }^{16}$

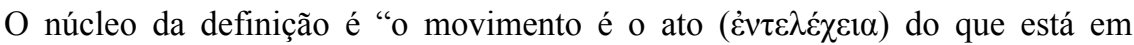
potência enquanto tal". As noções de ato e potência são, como dissemos, essenciais. O movimento é ato. Mas o que o distinguiria de outros atos que não são movimento? Aristóteles definiu a natureza como sendo "um princípio de movimento e de estabilidade". Um ser que existe apenas em ato, que não está em potência para algo, não se move. A pura potencialidade não existe, mas um ser em ato que está em potência para algo não se move enquanto não se tornar em ato aquilo que era em potência. $\mathrm{O}$ movimento, portanto, supõe que o ser esteja em uma condição intermediária entre o ato e a potência. É preciso que seja um ser em ato que esteja em potência para um outro ato e que vá se atualizando da potência a esse outro ato. Aristóteles dá o exemplo do quente

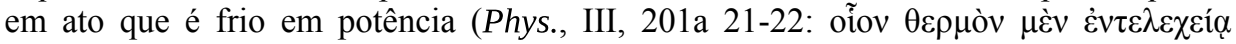

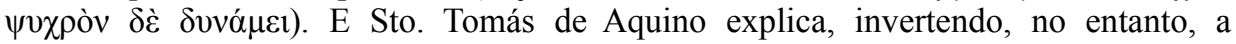
$\operatorname{ordem}^{17}$ :

Com efeito, quando a água é quente somente em potência, ainda não se move. Mas quando ela já está aquecida, terminou-se o movimento de aquecimento. Quando, porém, ela já tem uma certa participação no calor, mas de modo imperfeito, então ela se move em direção ao calor, pois aquilo que está sendo 
aquecido participa progressivamente do calor cada vez mais. Portanto, o próprio ato imperfeito do calor que existe naquilo que está sendo aquecido é um movimento; não certamente enquanto já está em ato apenas, mas na medida em que, já existindo em ato, tem uma ordenação a um ato ulterior, porque, se fosse suprimida a ordenação a um ato ulterior, o próprio ato, por mais imperfeito que fosse, seria o termo do movimento e não o movimento, assim como ocorre quando algo é aquecido parcialmente. [...] Portanto, o ato imperfeito tem razão de movimento, tanto na medida em que é comparado ao ato ulterior como potência, quanto na medida em que é comparado a algo mais imperfeito como ato. Donde ele nem é a potência do que existe em potência e nem é o ato do que existe em ato, mas é o ato do que existe em potência, de modo que, pelo fato de que se diz 'ato', designa-se a ordenação dele a uma potência anterior e, pelo fato de que se diz 'do que existe em potência', designa-se a ordenação dele a um ato ulterior. $^{18}$

O movimento não seria, portanto, uma potência, mas um ato. No entanto, ele não é um ato completo e simples, mas incompleto e imperfeito. $\mathrm{O}$ fato de que tenhamos algo em potência ou em ato, por exemplo, uma certa quantidade, não é razão suficiente para que haja movimento. Ao não colocar-se o movimento nem no ato pleno nem na potência, ele mostra-se algo efetivamente indefinido. No entanto, é preciso compreendê-lo conforme a definição que Aristóteles deu: o movimento é o ato

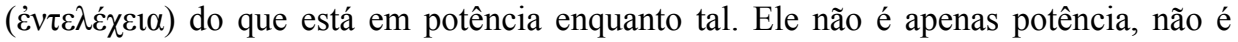
apenas ato, mas o ato de um ser que está em potência. Há nele uma certa mistura de ato e potência ${ }^{19}$, o que torna difícil entender o que é o movimento:

Uma causa pela qual parece que o movimento é indefinido é que não se pode colocá-lo nem em uma potência dos entes nem em um ato, pois nem uma quantidade potencial nem uma quantidade em ato se movem necessariamente. $\mathrm{O}$ movimento parece ser um certo ato, mas incompleto. A causa é que o potencial, do qual o movimento é ato, é incompleto. E por isso, efetivamente, é difícil compreender o que ele é, pois é preciso colocá-lo ou na privação ou na potência ou no ato simples; mas nada disso é aceitável. Resta, então, o modo que foi dito: $<$ o movimento $>$ é um certo ato, um ato tal como dissemos, difícil de se ver, mas aceitável. ${ }^{20}$

No livro V da Física, Aristóteles determina com mais precisão as categorias em que se encontra o movimento. No livro III (200b 26-28), ele mencionara a divisão do ser em ato e potência, o que se dá nas dez categorias, e o fizera porque tais noções são essenciais à definição de movimento. Ele citara explicitamente três categorias substância, quantidade e qualidade - , acrescentando, por fim, um extensivo "outras categorias do ser". Na interpretação de Averróis, como vimos, ele assim procedera por querer mostrar que o movimento ocorreria em apenas quatro categorias. Para além do movimento local ou deslocamento, que afeta a categoria onde, o movimento afetaria também a substância, a quantidade e a qualidade. A limitação do movimento a essas quatro categorias parece ser aceita por Sto. Tomás no comentário à passagem:

Diferem também as espécies de movimento, dentro de um mesmo gênero, segundo o perfeito e o imperfeito, pois, na substância, a geração é o movimento em direção à forma e a corrupção, à privação; e, na quantidade, o aumento, em direção à quantidade perfeita, a diminuição, à imperfeita. Por que, porém, não se atribuem duas espécies na qualidade e no onde, isso será mostrado no livro V. ${ }^{21}$

Essa restrição do movimento às quatro categorias citadas é, de resto, atestada por Aristóteles justamente nas Categorias: "Há seis espécies de movimento: geração, corrupção, aumento, diminuição, alteração, mudança segundo o lugar"22. Teríamos, 
assim: a geração e a corrupção afetando a substância; o aumento e a diminuição, a quantidade; a alteração atingindo a qualidade; a mudança segundo o lugar aplicando-se à categoria onde. Mas, no livro $\mathrm{V}$, a substância será excluída. Em 225a, Aristóteles desenvolve uma argumentação baseada na ideia de que toda mudança ( $\mu \varepsilon \tau \alpha \beta$ on partindo de uma coisa em direção a alguma outra coisa, o que ele confirma através do

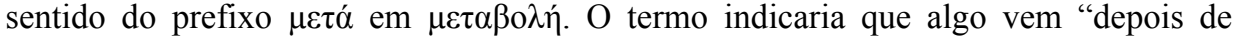
( $\mu \varepsilon \tau \alpha ́$ ) alguma coisa", ou seja, que uma coisa vem antes e outra, depois ${ }^{23}$. A coisa que se modifica ( $\tau$ ò $\mu \varepsilon \tau \alpha ́ \beta \alpha \lambda \lambda \lambda o v)$ sofreria o processo de mudança de quatro modos:

(a) de um sujeito a um outro sujeito;

(b) de um sujeito a um não-sujeito;

(c) de um não-sujeito a um sujeito;

(d) de um não-sujeito a um não-sujeito.

Com base nesses quatro modos, só haveria necessariamente três mudanças, já que o caso (d), mudança de um não-sujeito a um não-sujeito, não seria possível, pois aqui não se dá oposição entre o não-sujeito e o não-sujeito, visto que não são nem contrários nem contraditórios. A mudança segundo contradição que vai (c) de um nãosujeito a um sujeito seria uma geração, enquanto a mudança (b) de um sujeito a um nãosujeito seria uma corrupção. Mas é impossível que o não-ser se mova ${ }^{24}$, pelo simples fato de que não existe. Ele, propriamente falando, não é movido, mas gerado ${ }^{25}$. A geração, portanto, não é nem um movimento nem uma estabilidade ou repouso. A corrupção também não é um movimento, já que a um movimento só pode se opor um outro movimento ou a estabilidade (repouso). Mas como ficou demostrado que a geração não é nem um nem outra e a corrupção é seu oposto, ela também não pode ser um movimento. Dos três modos de mudança, ficam, pois, excluídos os dois que envolvem o não-ser, seja como termo a quo (item 'c'), seja como termo ad quem (item ' $b$ '). Resta que o movimento é uma mudança ( $\mu \varepsilon \tau \alpha \beta$ on $)$ que só se dá de um sujeito a um outro sujeito (a). A geração (c) e a corrupção (b) consistem em mudanças segundo a

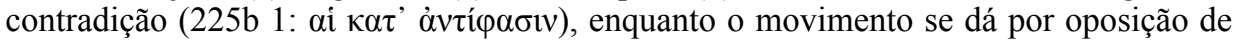
contrariedade entre dois termos (ou seus intermediários), o que só pode ocorrer na mudança de um sujeito a outro. Assim, são três as categorias em que há movimento: “é necessário haver três movimentos, o da qualidade, o da quantidade e o relativo ao lugar. Mas não há movimento em relação à substância pelo fato de não haver nenhum ente contrário à substância"26. E Aristóteles, retomando o tríplice movimento, aborda a questão da terminologia a ser aplicada a cada tipo de movimento:

Visto que não há < movimento $>$ nem de uma substância, nem de uma relação, nem de uma ação e de uma paixão, resta que só há movimento segundo a qualidade, a quantidade e o lugar, pois, em cada um desses, há contrariedade. Chamemos, portanto, de alteração o movimento segundo a qualidade, pois esse é o nome comum que $<$ a ele $>$ está conectado. Mas eu chamo de 'qualidade' não aquilo que está na substância (pois também a diferença é uma qualidade), mas o que é passivo, segundo o qual se diz que há paixão ou impassibilidade. $\mathrm{O}$ movimento segundo a quantidade é destituído de um nome comum, havendo, conforme cada uma das duas possibilidades, <os termos> 'aumento' e 'diminuição': o movimento até a grandeza perfeita é o aumento, e o que dela se afasta, a diminuição. $\mathrm{O}$ movimento segundo o lugar é destituído tanto de um nome comum quanto de um nome particular. Chamemo-lo comumente de deslocamento ( latio). ${ }^{27}$

O movimento, dentro das três categorias em que existe, pode, portanto, chamar- 
se:

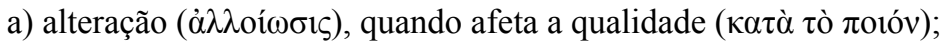

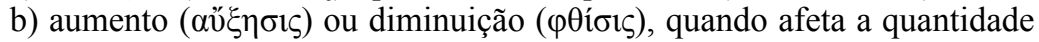

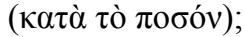

c) deslocamento (

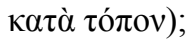

\section{O MOVIMENTO EM $D E A N I M A$ I E II}

Passemos, agora, à questão do movimento no De Anima. Não é nossa intenção e nem seria possível, nos limites de um artigo, esgotar a complexidade de tal assunto. E a razão é simples: o conceito de movimento e as funções que ele exerce na física de Aristóteles perpassam basicamente todo o De Anima. E a confirmação de que o estudo da alma esteja no âmbito da física é dada por uma passagem do início do De Anima: "E por isso efetivamente compete ao filósofo da natureza teorizar sobre a alma, seja toda $<\mathrm{e}$ qualquer $>$ alma, seja de tal tipo <que mencionamos $>$ "28. Isso ocorre, entre outros motivos, porque "as paixões são conceitos na matéria"29, isto é, têm o seu ser na matéria $^{30}$ ou são formas na matéria. E cabe ao filósofo da natureza tratar das paixões que são inseparáveis da matéria ${ }^{32}$.

Aristóteles inicia o estudo da alma pela parte doxográfica. Ele pretende compilar as principais opiniões de seus antecessores acerca do tema. E uma primeira característica geral da alma, bastante perceptível a qualquer um, está baseada na diferença que há entre os seres que chamamos de vivos e aqueles que são destituídos de vida, seja porque nunca a tiveram (uma pedra), seja porque a perderam (um cadáver). Chamamos os primeiros de "animados" ( $\tau \dot{\alpha}$ č $\mu \psi v \chi \alpha)$, pois possuem alma ( $\psi v \chi \eta ́)$, os segundos, de "inanimados" ( $\tau \grave{\alpha} \alpha \alpha \psi \psi v \chi \alpha$ ), pois dela são destituídos. A diferença que há entre eles consiste em duas atividades facilmente observáveis: o movimento e a sensação:

O ponto de partida da investigação é apresentar aquilo que mais parece pertencer a ela $<$ a alma $>$ por natureza. Ora, o animado parece diferir do inanimado, por natureza, especialmente em dois aspectos: o movimento e a percepção sensível. ${ }^{33}$

O movimento, aqui, tem o significado de movimento local ${ }^{34}$, que afeta a categoria onde. Trata-se de mover-se localmente e não ser movido por outro ${ }^{35}$. Os outros tipos de movimento (qualitativo e quantitativo) não são explicitamente mencionados, mas talvez estejam compreendidos no âmbito da sensação, que será estudada no livro II. Portanto, o movimento, em sua amplitude, é o elemento essencial para distinguir os seres vivos dos demais.

Ao longo do livro I, Aristóteles mostra como o conceito de movimento aparece em seus antecessores, com o intuito de descobrir o que de verdadeiro já se sabe sobre a alma e, ao mesmo tempo, evitar os eventuais erros. Para alguns deles, a alma é sobretudo o princípio motor ( $\tau$ ò Kıvoṽv) e, como tal, para que ela possar mover, deve

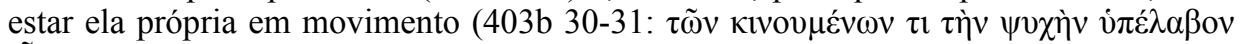
Eĩvol). Tendo repassado o pensamento de Demócrito sobre esse ponto, assim como dos pitagóricos e dos que dizem que a alma move a si mesma, ele conclui que:

todos esses, com efeito, parecem supor que o movimento é o que há de mais próprio à alma, e que todas as outras coisas são movidas pela alma, mas que ela é movida por si mesma, pelo fato de não verem nenhum motor que não esteja também ele próprio se movendo. ${ }^{36}$ 
Ao fechar a parte das opiniões dos filósofos e antes de começar a crítica a elas, ele resume as três características pelas quais costumam definir a alma: movimento,

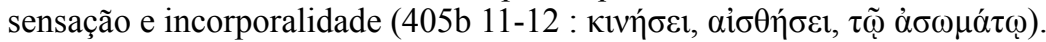

Na segunda parte do livro I (405b 31 e ss.), Aristóteles fará a análise crítica das opiniões que passara em revista na primeira parte. Ele abre essa seção aventando a possibilidade de que seja falsa a tese de que a substância da alma consista em que ela mova a si mesma e vai mesmo adiante: seria impossível que o movimento pertencesse a ela. Em sua argumentação, ele mencionará quatro movimentos: "Como há quatro movimentos - deslocamento, alteração, diminuição, aumento - ela poderia mover-se segundo um desses ou segundo vários ou segundo todos. ${ }^{37 "}$ Ora, ele fala de quatro movimentos, como o fizera no livro III da Física. No entanto, em sua enumeração, não estão a geração e a corrupção. E se atentarmos aos movimentos elencados, eles são os mesmos apresentados no livro V da Física. De fato, ele aí mencionara esses quatro movimentos, mas que se distribuíam em três categorias: o movimento segundo a quantidade é ou o aumento ou a diminuição. As quatro espécies de movimento elencadas não implicam que sejam afetadas quatro categorias, como em Física III, onde a substância aparecia como submetida ao movimento. Mas se a alma se mover por natureza segundo um desses movimentos, será preciso atribuir-lhe também um lugar. De fato, todos esses quatro movimentos estão em um lugar. É preciso, para compreender tal afirmação, entender que há uma diferença entre o movimento segundo o lugar e o movimento no lugar. O primeiro é o movimento local, o deslocamento ( referem à quantidade, não são movimentos segundo o lugar, mas no lugar, pois, para que eles ocorram, é preciso que o sujeito ocupe um lugar. No caso do aumento e da diminuição, o corpo, ao aumentar ou diminuir, ocupa mais ou menos espaço. No caso da alteração, para que ela ocorra, é necessário que aquele corpo que sofre a alteração ocupe um lugar e que esteja próximo ao que o altera. Este último deve, portanto, aproximar-se localmente do que sofre alteração ${ }^{38}$.

Um argumento interessante que Aristóteles apresenta para negar que a substância da alma é o mover-se a si mesma, ou, em outras palavras, que o movimento pertence a sua substância ou é a sua substância, é o seguinte:

No entanto, se ela move a si mesma, também está em movimento. E se todo movimento é deslocamento do movido enquanto é movido, por conseguinte também a alma se deslocaria de sua substância, supondo que se move não por acidente, mas sim que o movimento pertence à substância mesma por si mesma. ${ }^{39}$

Aquilo que se move quanto a algo, afasta-se desse algo. Por exemplo, se algo se move quanto a uma determinada cor, ele se afasta dessa cor e adquire uma nova. $\mathrm{O}$ mesmo ocorre quanto a uma determinada quantidade: aquele que se move quanto a ela, dela se afasta e adquire outra quantidade. Se a alma se movesse quanto a sua substância, afastar-se-ia desta e adquiriria nova substância, o que seria uma mudança de corrupção e geração, que, como se viu, não é propriamente um movimento. Em outras palavras, a alma mover-se quanto a sua substância significaria não mover-se, o que é uma contradição.

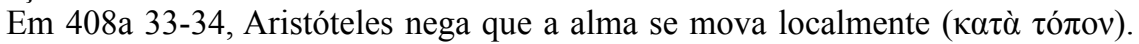
Insistindo no problema do movimento da alma, ele tece algumas considerações adicionais. Diz-se, comumente, que a alma se alegra, entristece-se, que ela sente ou

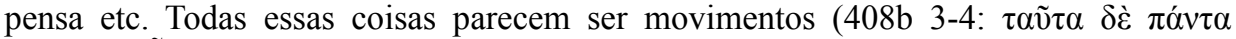

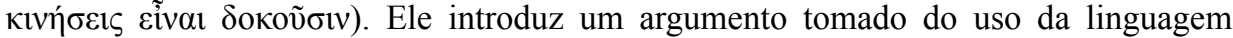
comum ( $\varphi \alpha \mu \varepsilon ́ v$ : nós dizemos), que seria um indício do movimento da alma, pois 
quando dizemos que a alma se entristece, isso significa que há um movimento com a tristeza e que, portanto, a alma se move ${ }^{40}$. Mesmo que se admita que essas atividades sejam movimentos e que eles sejam produzidos pela alma, nem por isso é necessário que a alma se mova. É possível entender que esses movimentos são a ela atribuídos como a uma causa. E nesse sentido seria melhor dizer que é o composto, nesse caso humano, que sofre tais paixões e que a alma é sua causa ${ }^{41}$ :

Com efeito, é melhor talvez não dizer que a alma sente pena ou aprende ou pensa, mas que é o homem que o faz pela alma. E isso não como se houvesse nela o movimento, mas sendo ela por vezes o termo, por vezes o ponto de partida $<$ dele $>$ : por exemplo, a sensação tem seu ponto de partida em tais objetos determinados, e a reminiscência parte dela $<\mathrm{a}$ alma $>$ e chega até os movimentos que estão nos órgãos sensoriais ou o que deles $<$ os movimentos $>$ permaneceu. ${ }^{42}$

A alma teria, assim, relação com o movimento, não por ser afetada por ele, mas por ser o termo a quo ou ad quem dele.

Terminado o livro I, Aristóteles, já desde o início do livro II, foca na noção ${ }^{43} \mathrm{de}$ alma mais geral que se poderia dar. Ele apresenta uma definição que caberia a toda e qualquer alma (412b 4: غ̇ंì $\pi \alpha ́ \sigma \eta \varsigma ~ \psi v \chi \tilde{\eta} \varsigma)$ : a alma "seria o ato primeiro de um corpo

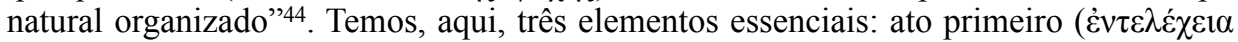

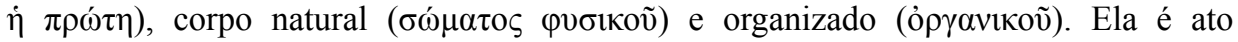
primeiro, isto é, entitativo ${ }^{45}$, o que significa que ela é forma. Como ele dissera pouco

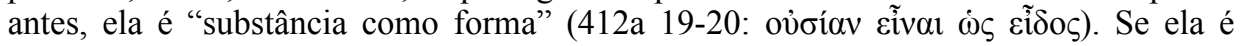
forma de um corpo, é porque esse é a matéria que é por ela informada. Temos, assim, o hilemorfismo aplicado ao composto que é todo e qualquer ser vivo: alma como forma animando uma matéria corpórea. $\mathrm{O}$ corpo que constitui o composto hilemórfico não é todo e qualquer corpo: é um corpo natural. Os corpos artificiais, como um machado, estão, por conseguinte, descartados de fazer parte de um composto em que a alma é forma. E ao dizer corpo natural, Aristóteles pretende que esse corpo seja tal que nele haja a natureza, que, como se disse, é princípio e causa do movimento e do repouso ${ }^{46}$. Ora, dentre os seres por natureza que Aristóteles dá como exemplo em Física $\mathrm{II}^{47}$, os primeiros são justamente os animados: plantas e animais. A mesma ideia surge pouco antes no De Anima, pois ele afirma que "sobretudo os corpos parecem ser substâncias e, dentre eles, os naturais, pois são princípios dos outros. Dentre os $<\operatorname{corpos}>$ naturais, uns têm vida, outros não a têm: e chamamos vida o fato de alimentar-se por si mesmo, o aumento e a diminuição" 48 , que são os atos mais elementares do vivente e sem os quais ele não poderá viver e, por conseguinte, exercer outras funções.

No livro $\Delta(\mathrm{V})$ da Metafísica, o filósofo repassa diferentes sentidos do termo púoıs. Um deles é o registrado em Física II: princípio do movimento nos seres

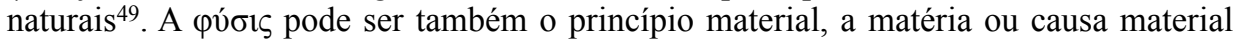
de um $\operatorname{ser}^{50}$. E com muito mais razão chama-se natureza a substância e a forma: "natureza é a matéria-prima...a forma e a substância"51. Se a natureza é forma e substância, a alma é a natureza do composto, sendo, por isso mesmo, princípio de movimento e repouso. Ela é o princípio e a causa daquilo que é próprio ao ser vivo: viver. E como viver compreende uma série de atividades - alimentar-se, crescer, alegrar-se, entristecer-se, sentir, pensar -, a alma é princípio delas todas e do movimento que implicam.

O corpo natural, para ser vivo, precisar ser "organizado", isto é, dotado de órgãos. Aristóteles não pretende com isso que o corpo, sendo ỏ $\gamma \alpha$ viкóv, seja um mero

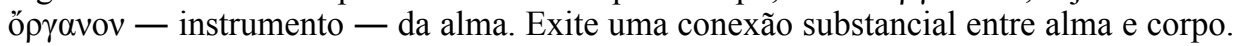
O termo "organizado", entendido como dotado de órgãos, indica que o corpo tem os 
diversos instrumentos necessários para que a alma exerça suas funções, lembrando, no entanto, o que foi há pouco mencionado: é melhor dizer que é o homem, isto é, o composto, que realiza todas as atividades por causa da alma. As funções vitais não são apenas da alma, o que fica evidente se pensarmos nas vegetativas: quando há o crescimento, não é a alma que cresce, e nem a matéria sem forma, é o composto, isto é, a matéria informada pela alma.

Se a alma é o que permite ao composto realizar suas diversas funções vitais, desde as mais básicas até as mais complexas, o animado difere do inanimado pela $v i_{a}{ }^{52}$. Esta se diz de muitos modos (413a 22: $\pi \lambda \varepsilon$ ov $\alpha \chi \tilde{\omega} \varsigma$ ) e basta que uma das funções da alma esteja presente para podermos dizer que algo vive. Assim, um ser vivo será dotado de uma ou mais funções tais como: intelecto, sensação, movimento e repouso locais, movimento nutritivo, diminuição e aumento ${ }^{53}$. Dessas atividades, movimento e repouso segundo o lugar, diminuição e aumento são considerados por Aristóteles movimentos, conforme já vimos. Aqui, ele fala da nutrição como um movimento, e nada diz da sensação e da intelecção. Na sequência, ele conclui: "a alma é o princípio dessas coisas mencionadas e está definida por elas, $<$ a saber $>$ pelo nutritivo, o sensitivo, o intelectivo, o movimento" 54 . Nem todos os seres vivos têm todas essas atividades. Uns possuem algumas e há os que possuem apenas uma, como as plantas, que possuem somente a faculdade nutritiva ${ }^{55}$. Esta compreende, além da nutrição, também a capacidade de aumento e diminuição ${ }^{56}$. E por isso Aristóteles a incluíra entre no âmbito do movimento. A faculdade nutritiva é a que exerce as funções mais básicas necessárias a toda e qualquer forma de vida ${ }^{57}$. Já o movimento local não é próprio de todo e qualquer vivente. Apenas uma parte o possui ${ }^{58}$.

Em 415a 16-20, Aristóteles estabelece que é preciso analisar os atos e operações de cada faculdade para melhor compreendê-la. Ele começa pele nutrição e pela geração, que são atividades próprias da faculdade nutritiva. Mas, em uma pequena digressão, ele afirma que "a alma é de onde vem, primeiramente, o movimento segundo o lugar" 59 . A faculdade nutritiva é responsável pela geração não do mesmo indivíduo, mas de um outro a ele semelhante. Através dela, há o aumento e a manutenção da espécie. A nutrição, por outro lado, é responsável pelo aumento e a manutenção do próprio indivíduo. Uma vez ingerido o alimento, há a digestão, processo pelo qual o alimento sofre uma alteração e é integrado ao vivente. Este tem sua quantidade aumentada e cresce (para o alto - o tronco - e para baixo - as raízes - , nas plantas, que também crescem em outras direções), havendo um movimento que não é um deslocamento (pois o vivente não deixa de estar em um lugar, ponto de partida, para estar em outro, ponto de chegada), mas que ainda sim ocorre no espaço.

Enquanto tratava da faculdade nutritiva, Aristóteles, em uma digressão, afirmou que "a sensação parece ser uma certa alteração"60. Ora, como a alteração implica o movimento dentro da categoria da qualidade, a sensação seria, ela também, um movimento. Ele retoma a ideia quando começa a tratar da faculdade sensitiva: "A sensação consiste em ser movido e ser afetado, como está dito, pois há a opinião de que ela é uma certa alteração"61. Antes de entrar no estudo dos diferentes sentidos, ele estabelece algumas noções gerais que afetam toda e qualquer sensação. A primeira delas é a de que esta é uma forma de alteração. Mais especificamente, ela está no domínio da paixão ( $\pi \alpha ́ \sigma \chi \varepsilon ı v)$ e não da ação. Sentir consiste, assim, em uma paixão e um movimento que os sensíveis realizam nos sentidos; não se trata de uma ação dos sentidos nos sensíveis, como bem explica Averróis ${ }^{62}$. Por isso, os sentidos estão entre as potências passivas. Em 417a 14, Aristóteles estabelece uma primeira identidade entre ser afetado

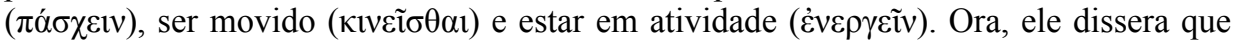
sentir é sofrer, é passividade, mas que é também um movimento. Este, porém, é um ato, 
como ficou determinado na Física. Como pode ser que sentir seja, ao mesmo tempo, paixão e ação? É porque o movimento, como dito em Física III, é um ato imperfeito, incompleto, isto é, um ato do que está em potência enquanto tal. Sentir, portanto, implica em um movimento, pois o sentido está em potência para o sensível. Este, ao agir sobre aquele, torna-o paulatinamente em ato. $\mathrm{O}$ processo de sensação consiste, assim, no movimento pelo qual o sentido, ao ser afetado pelo sensível, torna-se este em ato. Quando ele já é o sensível plenamente em ato, não há mais movimento. Aristóteles recupera, aqui, o que determinara sobre o movimento em Física III e menciona isto

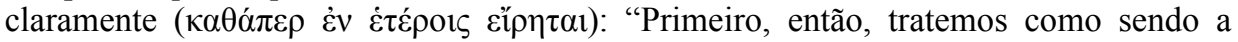
mesma coisa o ser afetado, o ser movido e o estar em atividade. Pois o movimento é uma certa atividade, todavia imperfeita, como foi dito alhures. ${ }^{63}$ "

Mas a noção de movimento não serve apenas para explicar processos vitais. $\mathrm{O}$ próprio movimento é considerado um objeto de conhecimento sensível, sendo enumerado entre os sensíveis comuns: " $<$ os sensíveis $>$ comuns são movimento,

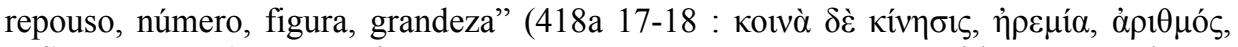
$\sigma \chi \tilde{\eta} \mu \alpha, \mu \varepsilon ́ \gamma \varepsilon \theta 0 \varsigma)$. O movimento não pertence a apenas um sentido, mas pode ser percebido por mais de um: "Com efeito, um movimento sensível ao tato o é também à

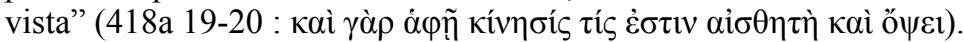

O conceito de movimento é utilizado para a compreenção do funcionamento dos diferentes sentidos. Assim, no que concerne à vista (ő $\psi 1 \zeta$ ), seu objeto é o visível (ópatóv). O visível é a cor $(\chi \rho \tilde{\omega} \mu \alpha)^{64}$ e esta é o que move o diáfano que está em ato. Diáfano, é, por definição, o que é transparente. Aristóteles dá como exemplo o ar e a água. Mas o diáfano não se atualiza senão pela luz: é preciso esta, para que se possa ver

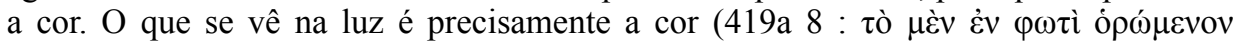
$\chi \rho \tilde{\omega} \mu \alpha)$. E o que faz com que a cor seja cor é precisamente sua capacidade de mover o diáfano que está em ato ${ }^{65}$. Um elemento necessário para a visão é o meio, sem o qual não há sensação. $O$ funcionamento da visão dá-se assim: a cor, que está na superfície dos objetos visíveis, move o diáfano que está em ato (por exemplo, o ar ou a água); o diáfano, uma vez movido pela cor, move o sentido, ou melhor, o órgão do sentido, que no caso da visão seria o olho. E é preciso que o meio (no caso, o diáfano) esteja em contato com o órgão do sentido para poder movê-lo. É assim que um objeto, mesmo muito distante, pode ser percebido pela visão: há um movimento que percorre o espaço entre o órgão e a cor do objeto e esse movimento se propaga através de um meio, que é o diáfano. É o que Aristóteles explica, resumidamente, da forma seguinte: "Mas a cor, por um lado, move o diáfano (por exemplo, o ar), e o órgão sensível, por sua vez, é movido por este $<0$ diáfano $>$, que lhe está contíguo" $" 66$.

Esse processo é o mesmo para os demais quatro sentidos, guardadas as diferenças que há entre eles. É preciso o meio, que é movido pelo objeto e que, em seguida, move o órgão sensorial. Em relação à audição e ao olfato, é assim que se passa: "O raciocínio sobre o som e o odor é o mesmo: com efeito, nenhum deles produz a sensação tocando o órgão sensorial, mas o meio é movido pelo odor e pelo som e cada um dos órgãos sensoriais é por ele movido"67.

Aristóteles procede à análise dos sentidos começando pelo "melhor" deles (a visão) e terminando no mais necessário (o tato ${ }^{68}$. Tendo visto os três primeiros sentidos, resta analisar o gosto e o tato, que têm uma certa semelhança, pois "o objeto do gosto é um certo tangível" ${ }^{\prime 69}$. Esses dois sentidos são diversos dos outros, pois o meio de que precisam para funcionar não é estranho ao próprio vivente, como acontece na visão, na audição e no olfato, que percebem seus objetos a distância. Aristóteles não afirma que o gosto e o tato não necessitam de um meio, mas que este não é um corpo intermediário estranho ao animal ${ }^{70}$. Tal meio é, como ele dirá mais adiante ${ }^{71}$, a carne. A 
umidade não é o meio pelo qual o objeto do gosto é conhecido. Ela é uma condição necessária para que haja a percepção sensorial, exatamente como a luz no caso da visão. O meio da visão é o diáfano, mas sem a luz não pode haver percepção. O mesmo ocorre com a umidade no que diz respeito ao gosto. $\mathrm{O}$ órgão do paladar não está úmido em ato, apenas em potência, e ele torna-se tal em ato pela ação do objeto, que como tal, é úmido. Aristóteles menciona uma umidade primária (422b 6-7) que seria um impedimento para a percepção do sabor. Essa umidade poderia ser algo inerente à própria língua ou, como no exemplo que ele dá, uma umidade prévia resultante de uma percepção sensorial anterior: "como quando alguém, tendo previamente provado um forte sabor, prova um outro" "72. O sentido do gosto é, assim, em potência tal coisa e o objeto é o que o faz tal em ato. Ele sofre, portanto, uma ação por parte de seu objeto enquanto este é perceptível pelo sentido ${ }^{73}$. Na verdade, no caso dos três primeiros sentidos, o objeto move o meio e este, o sentido. No gosto e no tato, é um pouco diverso, como já veremos. O processo de percepção do sabor implica, de todo modo, o movimento, conceito, de resto, contido na noção de passagem de potência a ato no órgão afetado pelo objeto.

Ao iniciar o estudo do último dos cinco sentidos, o tato, Aristóteles retoma uma questão que deixara em aberto: o objeto desse sentido. De fato, em 418 a 1 e ss., ele menciona os sensíveis próprios. O tato tem como objeto um grande número de diferenças. Ele trata, portanto, inicialmente, do problema da pluralidade de objetos do tato e se este constituiria um único sentido ou se seriam vários os sentidos do tato. $\mathrm{Na}$ sequência, ele explora o problema que mencionara um tanto antes, quando de seu estudo do gosto: qual é o meio ( è $_{\mu \varepsilon \tau \alpha \xi u ́)}$ que atua no funcionamento do tato e do gosto. A carne, diz ele, não é o órgão do tato, como a língua não o era do gosto; ela é

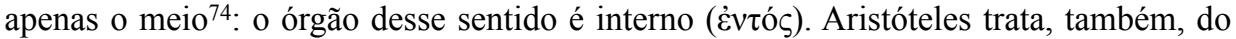
problema da semelhança ou diferença entre os sentidos a distância (visão, audição, olfato) e os chamados sentidos de contato (gosto e tato) ${ }^{75}$. Em ambos os tipos está envolvido o conceito de movimento, mas o funcionamento seria diverso. Nos sentidos a distância, o objeto move o meio (ar, água) e este, por sua vez, move o sentido. Nos sentidos de contato, a coisa se dá de modo diverso: o objeto é percebido não pela ação do meio, mas junto com o meio ${ }^{76}$. E Aristóteles dá como ilustração o soldado que é atingido através de seu escudo: não é que este seja atingido primeiro e depois transfira o golpe ao soldado; ambos são atingidos simultaneamente pelo golpe. O escudo, que é o meio, é a imagem da carne para o tato e da língua para o gosto. Estes são os meios e não os órgãos, que são internos. E é preciso, do mesmo modo que nos sentidos a distância, que haja movimento para que ocorra a sensação. No entanto, a diferença reside na simultaneidade ( $\alpha \mu \alpha)$ da ação do objeto, que move, ao mesmo tempo, o meio e o sentido.

Após a análise de cada sentido e objeto em particular, Aristóteles, no final do

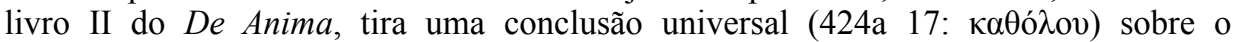
funcionamento dos sentidos e uma sua definição: o sentido é aquilo que é receptivo das formas sensíveis sem a matéria. A definição tem três elementos, o primeiro dos quais é

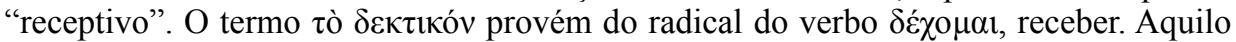
que é receptivo, isto é, apto a receber algo, está em uma condição de passividade e de potencialidade. Ao dizer que o sentido é algo apto a receber as formas sensíveis, Aristóteles insiste na ideia de que a sensação é, da parte do sentido, uma paixão, o sofrer a ação do sensível, e que o sentido está em potência para tornar-se em ato o

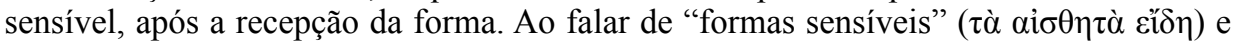

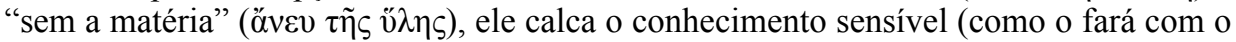
intelectivo) no âmbito do hilemorfismo e estabelece a ideia de que o conhecimento tem 
como objeto a forma e deve abstrair, de algum modo, da matéria concreta. O exemplo que ele emprega para ilustrar sua afirmação é a cera, que é capaz de receber a impressão de um anel de metal sem, no entanto, receber a matéria do anel, isto é, o metal. A cera não se torna metal. O mesmo ocorre com o sentido: ele sofre uma ação ( $\pi \alpha ́ \sigma \chi \varepsilon \iota)$ da parte de um objeto que tenha cor, sabor ou som, mas não enquanto cada objeto é tal natureza particular, mas enquanto ele é tal qualidade e segundo sua forma. Em outras palavras, o sentido conhece, por uma recepção que é obviamente passiva ( $\pi \alpha ́ \sigma \chi \varepsilon ı)$, não a substância da coisa, mas uma qualidade, e ele não adquire essa nova qualidade de modo material, perdendo suas próprias qualidades, mas de modo formal ou intencional. Como explica Averróis, "se ele (o sentido) as recebesse (isto é, as formas) com a matéria, então essas teriam o mesmo ser na alma e fora da alma"77.

No processo de sensação, é possível que haja uma alteração do sentido, sobretudo no tato e no gosto, que pelo "contato" de seus objetos, estão mais expostos a tal. Assim, além de uma alteração imaterial, eles podem sofrer aquecimento ou resfriamento por ação do objeto. Essa alteração constitui uma mudança na qualidade do órgão e, portanto, um verdadeiro movimento. Mas todos os sentidos têm seu funcionamento baseado em uma alteração que é de outro tipo. Normalmente, fala-se de alteração quando um ser adquire uma qualidade, perdendo outra que possuía. Assim, algo branco, ao tornar-se negro, sofre uma mudança, uma alteração, que é um movimento. Perde uma qualidade e ganha outra. Quando a visão recebe uma cor, isto se dá de modo imaterial, ela não adquire essa nova qualidade, ela não perde uma cor sua preexistente para receber a nova. Há, portanto, um outro modo de alteração. Que se trate de uma alteração, é o próprio Aristóteles que o afirma. Assim, por exemplo: "Há tanto alteração quanto crescimento em virtude da alma: com efeito, a sensação parece ser uma certa alteração"78. Em outra passagem, ele claramente associa a sensação ao movimento e à paixão (passividade) e a uma forma de alteração: "A sensação consiste

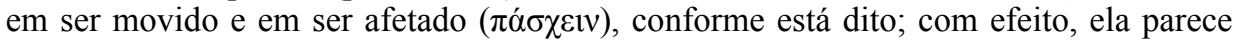
ser uma certa alteração"79.

Haveria duas formas de alteração. Uma implica a mudança a uma disposição contrária pela qual se ficará privado de uma disposição anterior. Seria o caso de algo branco que, ao tornar-se negro, deixa de ser branco. A outra alteração corresponde a uma mudança em direção a um hábito sem que haja a perda do que quer que seja. Assim seria a sensação, o conhecimento sensível, pois o cognoscente adquire uma nova forma acidental, uma qualidade, de modo imaterial, sem perder nada, sem que essa alteração represente a perda de uma qualidade intrínseca ao sentido ${ }^{80}$. O processo de conhecimento dos sentidos envolve, em seu bojo, o conceito de movimento e consiste, portanto, em uma forma de alteração do sentido que não é material (exceto acidentalmente), mas imaterial ou intencional, e que consiste em um movimento, de modo que, como disse Aristóteles a sensação consiste em ser movido.

\section{Conclusão}

O conceito de movimento é, como dissemos, essencial para a compreensão de transformações diversas a que estão submetidos os seres do mundo sublunar. Em sua definição entram as noções de ato e potência, das quais Aristóteles se serve para tentar fazer-nos compreender essa realidade complexa que é o movimento, que também está conectado à noção de natureza, já que esta é definida como uma causa do movimento e do repouso. A dificuldade de apreensão e definição do movimento está consubstanciada na própria hesitação de Aristóteles, que em Física III e em Categorias inclui a 
substância como submetida ao movimento e em Física $\mathrm{V}$ a exclui, restringindo o movimento a três categorias: qualidade, quantidade e lugar. É precisamente nessas categorias que veremos ocorrer os diferentes fenômenos vitais que Aristóteles estuda no De Anima. No livro III, ele trata do movimento local (

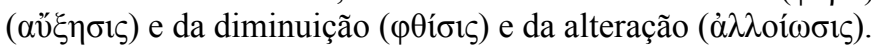

60 O De Anima, como um tratado que se insere no domínio da filosofia da natureza e que, portanto, depende das teorias desenvolvidas na Física, aplica, aos seres particulares que estuda (os animados), o conceito de movimento, que toma, inclusive, como um elemento fundamental para a própria definição de alma. Assim, a dinâmica da vida explica-se como uma série de manifestações de movimento e a compreensão das teorias que Aristóteles expõe no De Anima depende do reto entendimento do conceito de movimento e de sua conexão com as categorias em que ocorre.

\section{REFERÊNCIAS}

ARISTÓTELES. Aristotle's Physics. A revised text with introduction and commentary by W. D. Ross. Oxford: Oxford Univ. Press, 1936.

ARISTÓTELES. Aristotle's Metaphysics. A revised text with introduction and commentary by W. D. Ross Oxford: Oxford Univ. Press, 1970. v. 1-2

ARISTÓTELES. Catégories. Texte établi et traduit par Richard Bodéüs. 1. éd., 2. tirage ed. Paris: Les Belles Lettres, 2002.

ARISTÓTELES. De l'âme. Texte établi par A. Jannone. Traduction et notes de E. Barbotin. Troisième tirage. Paris: Les Belles Lettres, 1989.

AVERRÓIS. Aristotelis de physico auditu libri octo, cum Averrois Cordubensis variis in eosdem commentariis. Venetiis: apud Iunctas, 1562. v. IV

AVERRÓIS. Commentarium Magnum in Aristotelis De Anima Libros. Recensuit F. Stuart Crawford. Cambridge, Massachusetts: The Mediaeval Academy of America, 1953.

BODÉÜS. Ver Aristóteles. Catégories.

RODIER, G. Aristote, Traité de l'âme: commentaire. Paris: J. Vrin, 1985.

ROSS (1936). ver ARISTÓTELES. Aristotle's Physics.

TEMÍSTIO. Themistii in libros Aristotelis De Anima paraphrasis. Ed. Ricardus Heinze. Berolini: Typis et impensis Georgii Reimeri, 1899. v. 5,3

TEMÍSTIO. Themistii in Aristotelis Physica paraphrasis. Ed. Henricus Schenkl. Berolini: Typis et impensis Georgii Reimeri, 1900. v. 5,2

TOMÁS DE AQUINO. In Aristotelis librum De Anima Commentarium. Cura ac studio P. F. Angelus M. Pirotta OP. Taurini, Romae: Marietti, 1948.

TOMÁS DE AQUINO. In octo libros Physicorum Aristotelis Expositio. Cura et studio. P. M. Maggiòlo OP. Taurini, Romae: Marietti, 1965.

\section{NoTAS}

1 Cf. Sto. Tomás de Aquino, in De An., I, 1. 3, n.1.

2 Averróis, in Phys., prooemium, f. 3r C-3v G: "Ordo autem huius libri est quod iste liber est primus librorum positorum ab Aristotele in scientia naturali, quia res naturales dividuntur ad diversas naturas et, cum diversantur in eo quod est proprium unicuique eorum (sic) communicant tamen in rebus communibus existentibus in eis. Et propter hoc dividitur consideratio huius artis in duas partes. Prima est consideratio in rebus communibus omnibus rebus naturalibus; secunda est consideratio in rebus propriis unicuique generi naturarum diversarum. Et ista pars secunda dividitur secundum numerum diversorum generum, et propter hoc fuerunt libri positi in hac arte plures, sicut accidit in Logica et aliis artibus speculativis."

3 Sto. Tomás de Aquino, in Phys., I, 1. 1, 2: "Sciendum est igitur quod quaedam sunt quorum esse 
dependet a materia, nec sine materia definiri possunt: quaedam vero sunt quae licet esse non possint nisi in materia sensibili, in eorum tamen definitione materia sensibilis non cadit. Et haec differunt ad invicem sicut curvum et simum. Nam simum est in materia sensibili, et necesse est quod in eius definitione cadat materia sensibilis, est enim simum nasus curvus; et talia sunt omnia naturalia, ut homo, lapis: curvum vero, licet esse non possit nisi in materia sensibili, tamen in eius definitione materia sensibilis non cadit; et talia sunt omnia mathematica, ut numeri, magnitudines et figurae. Quaedam vero sunt quae non dependent a materia nec secundum esse nec secundum rationem; vel quia nunquam sunt in materia, ut deus et aliae substantiae separatae; vel quia non universaliter sunt in materia, ut substantia, potentia et actus, et ipsum ens."

4 Sto. Tomás de Aquino, in Phys., I, 1. 1, 3: "Quaedam vero sunt quae non dependent a materia nec secundum esse nec secundum rationem; vel quia nunquam sunt in materia, ut deus et aliae substantiae separatae; vel quia non universaliter sunt in materia, ut substantia, potentia et actus, et ipsum ens. De huiusmodi igitur est metaphysica. De his vero quae dependent a materia sensibili secundum esse sed non secundum rationem, est mathematica. De his vero quae dependent a materia non solum secundum esse sed etiam secundum rationem, est naturalis, quae physica dicitur." Cf. Aristóteles, De An., I, 403b 916.

5 Sto. Tomás de Aquino, in Phys., I, 1. 1, 3: "Et quia omne quod habet materiam mobile est, consequens est quod ens mobile sit subiectum naturalis philosophiae. Naturalis enim philosophia de naturalibus est; naturalia autem sunt quorum principium est natura; natura autem est principium motus et quietis in eo in quo est; de his igitur quae habent in se principium motus, est scientia naturalis."

6 Sto. Tomás de Aquino, in Phys., I, 1. 1, 4: "Sequuntur autem ad hunc librum alii libri scientiae naturalis, in quibus tractatur de speciebus mobilium: puta in libro De Caelo de mobili secundum motum localem, qui est prima species motus; in libro autem De Generatione, de motu ad formam et primis mobilibus, scilicet elementis, quantum ad transmutationes eorum in communi; quantum vero ad speciales eorum transmutationes, in libro Meteororum; de mobilibus vero mixtis inanimatis, in libro de Mineralibus; de animatis vero, in libro De Anima et consequentibus ad ipsum."

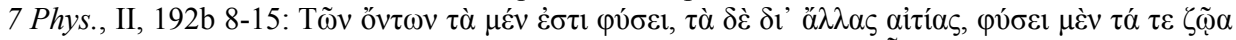

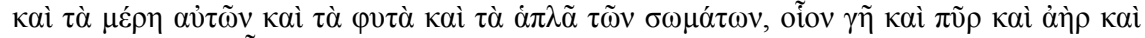

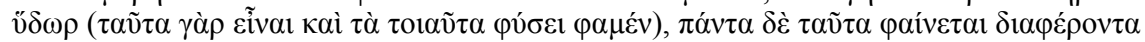

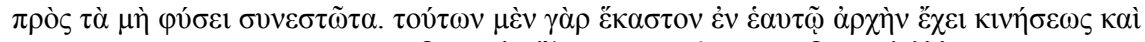

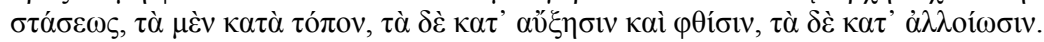

8 Aristóteles menciona especificamente a arte ( $\tau \dot{\varepsilon} \chi \vee \eta)$ em 192b 18. Temístio, em sua paráfrase (in Phys., 35, 4-9), inclui outras possibilidades: "por outras causas, por exemplo, uma cama, um banco, uma função de estratego, uma descoberta de um tesouro (dessas coisas, com efeito, umas são por causa da arte, outras por causa do acaso, outras por causa da deliberação); por causa da natureza, são os animais e suas partes; com efeito, as partes das coisas que são por natureza também são por natureza, e não é assim com as coisas

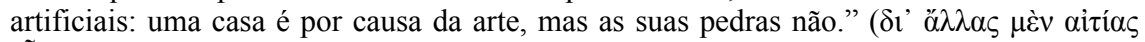

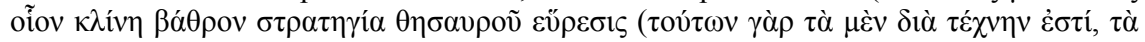

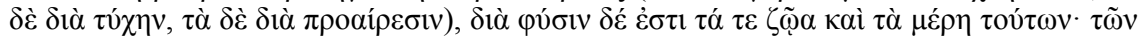

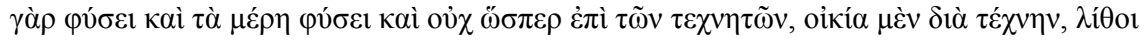

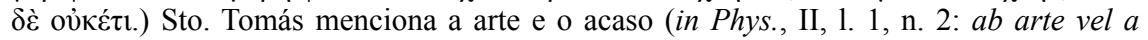
casu). Averróis fala da vontade e do acaso (in Phys., II, 1, f. 48r C: et intendit per alias causas voluntatem et casum).

9 Averróis, in Phys., II, 1, f. 48r D-E: "Deinde numeravit modos transmutationis e dixit 'quaedam in loco'. Et in hoc collocantur quatuor elementa et habentia animas e corpora coelestia, etsi principium in istis dicatur fere aequivoce: sed tamen in talibus descriptionibus non potest quis facere plus isto. Deinde dicit 'et quaedam in augmento'. Et innuit principium transmutationis propriae in vegetabilibus, et augmentum. Et cum dixit 'et quaedam in alteratione', intendit transmutationem in substantia, quae dicitur generatio et corruptio, et transmutationem in qualitate, quae dicitur alteratio." 


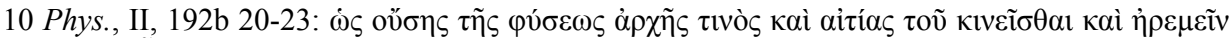

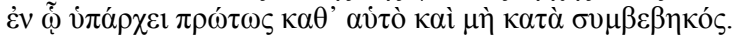

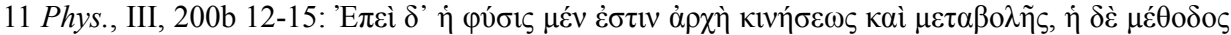

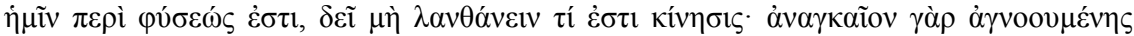
$\alpha$

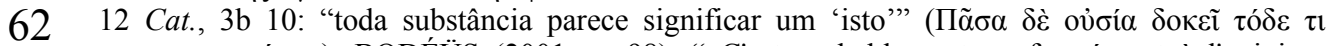

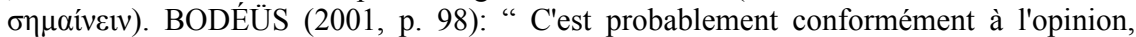
qu'Aristote emploie l'expression « une chose précise » ( $\tau$ ó $\varepsilon \varepsilon \tau \imath$ : littéralement, « quelque ceci » ou « un ceci en quelque sorte »). L'expression est utilisée pour désigner, sans la nommer et faute de pouvoir la nommer autrement, la sorte de chose que constitue une substance en elle-même, indépendamment des accidents qu'on peut lui attribuer : Socrate, qui constitue en lui-même une " chose précise », différente du blanc et de tout le reste qui lui appartient."

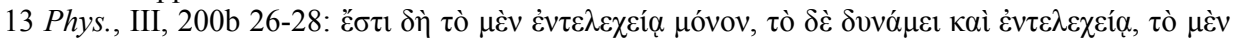

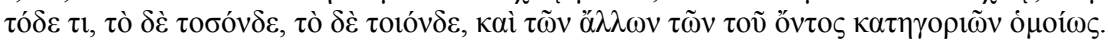

14 Averróis, in Phys., III, 3, f. 86v I: "deinde posuit secundam propositionem, et est quod entia dividuntur in decem praedicamenta, ad hoc quod vult etiam declarare quod motus invenitur in quatuor eorum tantum."

15 Sto. Tomás de Aquino, in Phys., III, 1. 2, n.3: "Potentia autem et actus, cum sint de primis differentiis entis, naturaliter priora sunt motu: et his utitur philosophus ad definiendum motum."

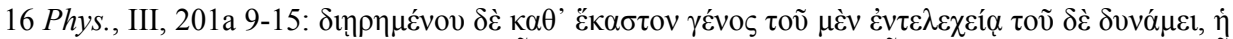

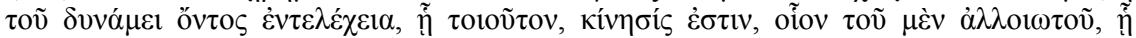

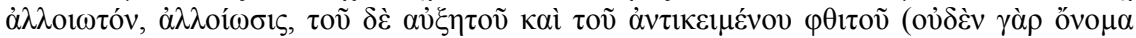

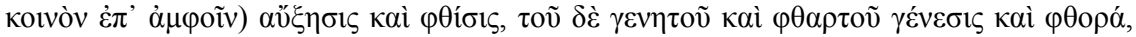

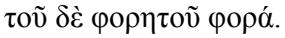

17 A explicação dessa inversão reside em uma simples variante textual. Ross (1936, ad locum)

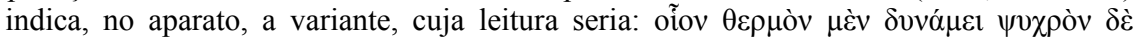
$\varepsilon \dot{\varepsilon} \tau \varepsilon \lambda \varepsilon \chi \varepsilon i ́ \alpha$.

18 Sto. Tomás de Aquino, in Phys., III, 1. 2, n. 3: "Cum enim aqua est solum in potentia calida, nondum movetur: cum vero est iam calefacta, terminatus est motus calefactionis: cum vero iam participat aliquid de calore sed imperfecte, tunc movetur ad calorem; nam quod calefit, paulatim participat calorem magis ac magis. Ipse igitur actus imperfectus caloris in calefactibili existens, est motus: non quidem secundum id quod actu tantum est, sed secundum quod iam in actu existens habet ordinem in ulteriorem actum; quia si tolleretur ordo ad ulteriorem actum, ipse actus quantumcumque imperfectus, esset terminus motus et non motus, sicut accidit cum aliquid semiplene calefit. [...] Sic igitur actus imperfectus habet rationem motus, et secundum quod comparatur ad ulteriorem actum ut potentia, et secundum quod comparatur ad aliquid imperfectius ut actus. Unde neque est potentia existentis in potentia, neque est actus existentis in actu, sed est actus existentis in potentia: ut per id quod dicitur actus, designetur ordo eius ad anteriorem potentiam, et per id quod dicitur in potentia existentis, designetur ordo eius ad ulteriorem actum. Unde convenientissime philosophus definit motum, dicens quod motus est entelechia, idest actus existentis in potentia secundum quod huiusmodi."

19 Sto. Tomás de Aquino, in Phys., III, 1. 3, n. 6: "Refletir sobre um tal ato é difícil por causa da mistura de ato e potência" (Talem autem actum considerare difficile est propter permixtionem actus et potentiae).

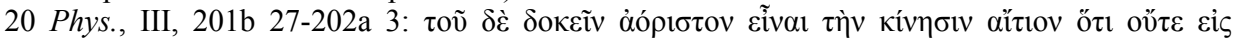

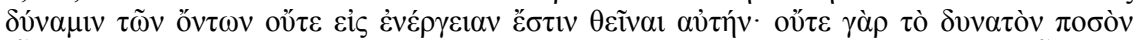

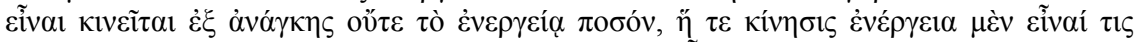

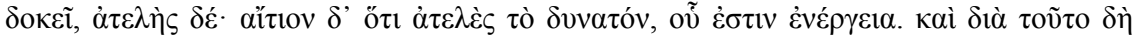

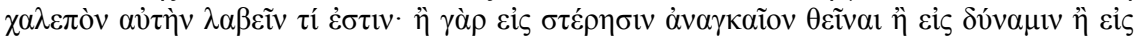

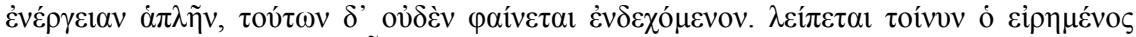

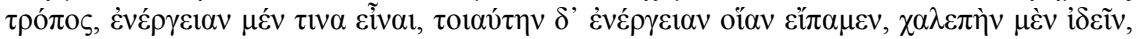
$\dot{\varepsilon} v \delta$ 


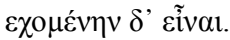

21 Sto. Tomás de Aquino, in Phys., III, 1. 1, n. 8: Differunt etiam species motus secundum perfectum et imperfectum in eodem genere: nam generatio est motus in substantia ad formam, corruptio vero ad privationem; et in quantitate augmentum ad quantitatem perfectam, diminutio ad imperfectam. Quare autem non assignentur duae species in qualitate et in ubi ostendetur in quinto.

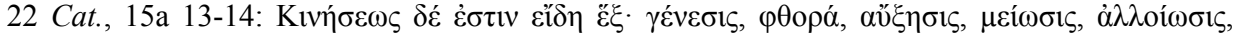

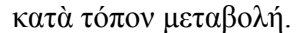

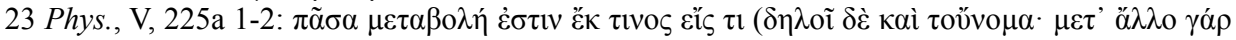

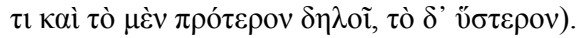

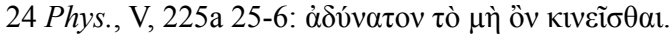

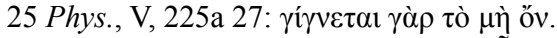

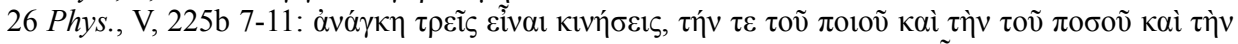

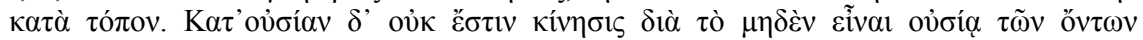
غ̇vavtíov.

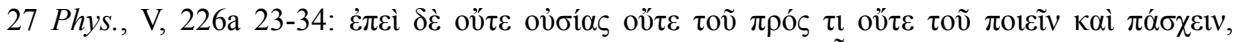

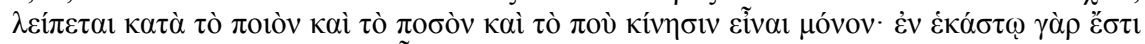

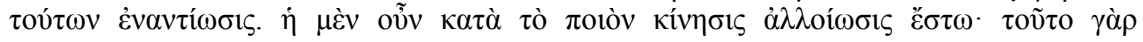

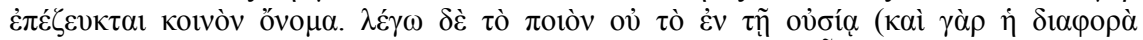

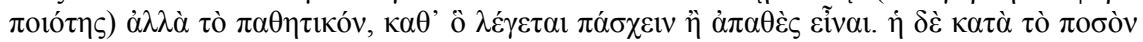

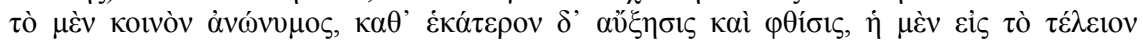

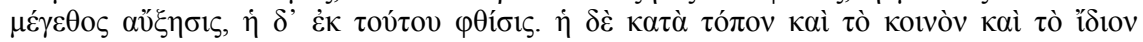

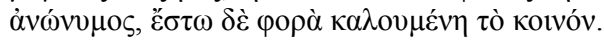

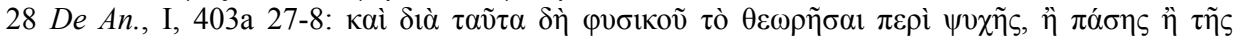

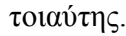

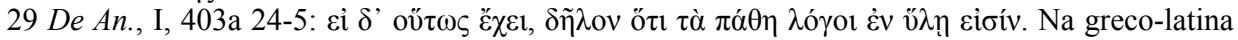
de Moerbeke: "Si autem sic habet, manifestum quod passiones rationes in materia sunt." $\mathrm{Na}$ árabo-latina: "Unde manifestum est quod passiones anime sunt intentiones in materia." Temístio, in De An., 7, 23-27: "E se essas coisas são desse modo, é evidente que essas paixões e outras tantas semelhantes são conceitos na matéria ( $\lambda$ ó isto é, que têm o ser na matéria. De modo que também os que definem cada uma delas $<$ as paixões $>$ não as separarão da matéria subjacente, como o que define a ira uma ebulição do sangue ao redor do coração, por causa do desejo de vingança." ( $\varepsilon \dot{i} \delta \dot{\varepsilon} \tau \alpha \tilde{v} \tau \alpha$

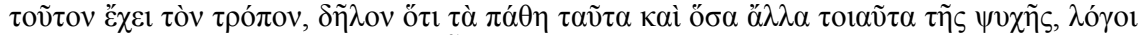

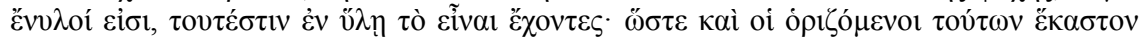

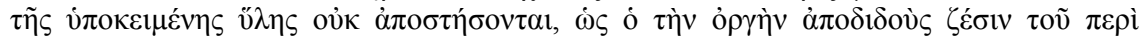

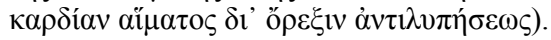

30 Cf. Sto. Tomás de Aquino, in De An., I, 1. 2, n. 7.

31 Cf. Averróis, in De An., I, comm. 14, p. 21, $42-44$.

32 De An., I, 403b 10-2: "É o filósofo da natureza <que trata> de todas as atividades e paixões

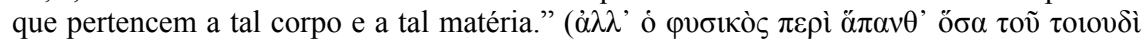
$\sigma \omega ́ \mu \alpha \tau$ n. 12: "Não há ninguém que examine as paixões da matéria não separáveis exceto o filósofo da natureza." (Non est enim aliquis qui consideret passiones materiae non separabiles nisi physicus).

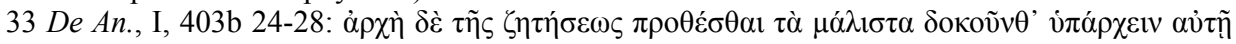

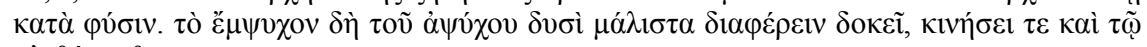
$\alpha i \sigma \theta \dot{v} v \varepsilon \sigma \theta \alpha 1$.

34 Cf. Averróis, in De An., I, comm. 19, p. 26, 21-22.

35 Sto. Tomás de Aquino, in De An., I, 1. 3, n. 2: "Nam animata videntur differre ab inanimatis maxime motu, ut scilicet moveant seipsa, et sensu seu cognitione." Temístio, in De An., 9,

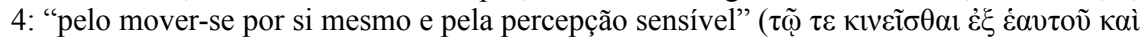
$\tau \tilde{\omega} \alpha i \sigma \theta \alpha \dot{v} \varepsilon \sigma \theta \alpha \imath)$.

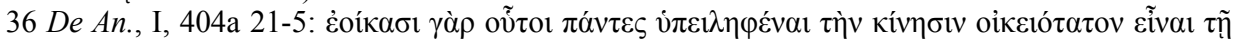

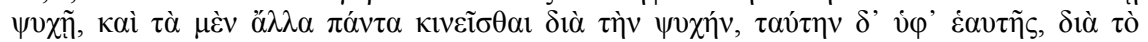




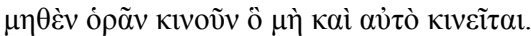

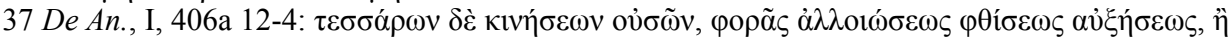

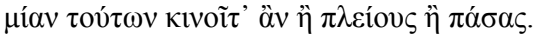

38 Cf. Sto. Tomás de Aquino, in De An., I, 1. 6, n. 9.

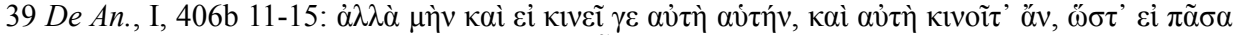

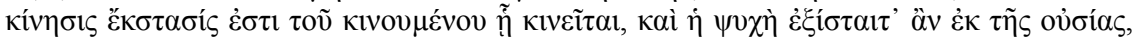

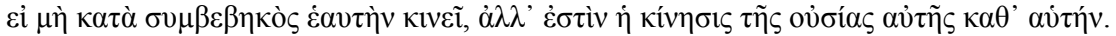

40 Averróis, in De An., I, comm. 62, p. 83, 12-14: "Et propter has duas propositiones existimatur quod anima movetur. V. g., anima contristatur; et cum tristitia est motus, ergo anima movetur."

$41 \mathrm{O}$ dativo grego $\tau \tilde{\eta} \tilde{\psi} \psi \chi \underline{n}$ não indica que a alma seria um instrumento do corpo, como o machado pode ser o instrumento do homem. O sentido não é instrumental, mas causal, como explica Temístio (in De An., 28, 9): "Diz-se, por conseguinte, que somos movidos pela alma quanto a esse movimento, porque a alma é para nós causa da paixão dos órgãos sensoriais e da transmissão através deles, visto que tal paixão não atinge os órgãos dos

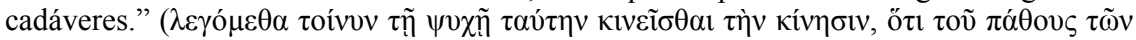

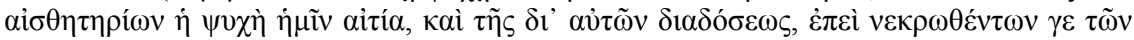

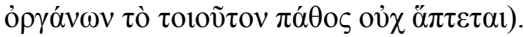

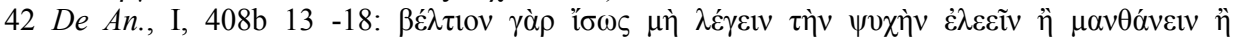

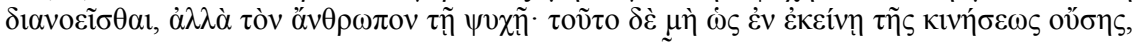

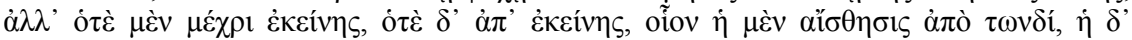

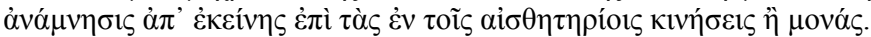

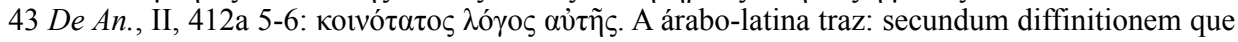
magis comprehendit ipsam; a greco-latina: comunissima ratio ipsius.

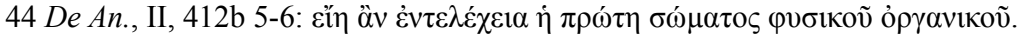

45 Sto. Tomás de Aquino, Sum. Theol., I, q. 48, a. 6: "O ato é duplo: há o ato primeiro e o ato segundo. O ato primeiro é a forma e a integridade da coisa; o ato segundo é a operação." (Actus autem est duplex: primus, et secundus. Actus quidem primus est forma et integritas rei: actus autem secundus est operatio).

46 Cf. nota 10 (Phys., II, 192b 20-23).

47 Cf. nota 7 (Phys., II, 192b 8-15).

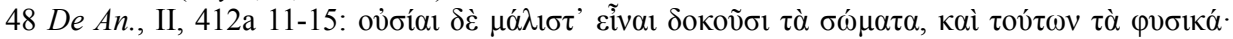

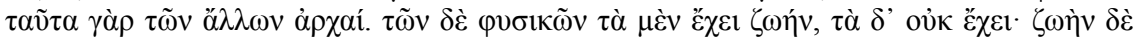

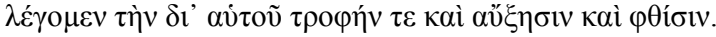

49 Met., $\Delta, 1014$ b 18-20: "ainda, <natureza é> de onde vem o primeiro movimento em cada um dos seres naturais $<$ e que $>$ está nele enquanto ele." [isto é: enquanto é um ser natural] (ह̌ $\tau \imath$

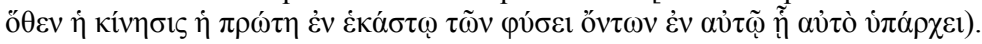

50 Cf. Met., $\Delta, 1014$ b 26-28.

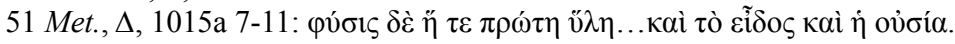

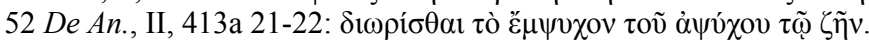

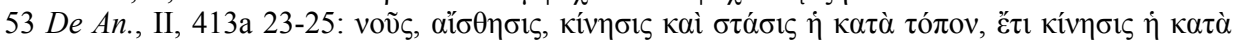

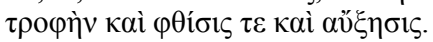

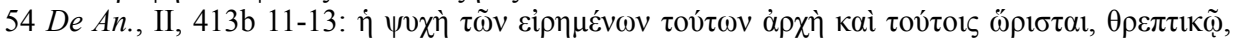

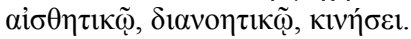

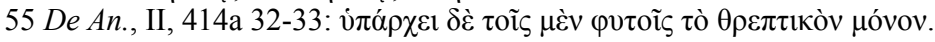

56 Averróis, in De An., II, comm. 27, p. 168, 27-29: Et intendit per nutritivam omnia principia que agunt in nutrimento; et sunt tria, scilicet nutritivum et augmentativum et diminutivum.

57 Sem a faculdade nutritiva, não pode haver a faculdade sensitiva. Há, portanto, uma gradação entre as diferentes faculdades (415a 1-3): “Com efeito, sem o nutritivo não há sensitivo;

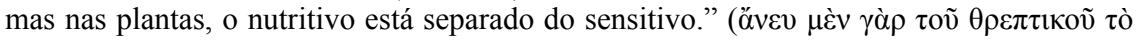

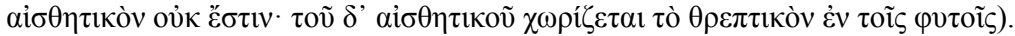

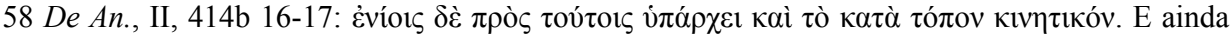
(415a 6-7): Entre os <animais> dotados de sensibilidade, uns têm o movimento local,

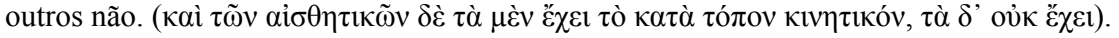




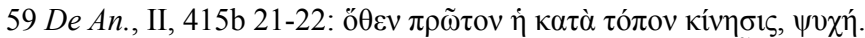

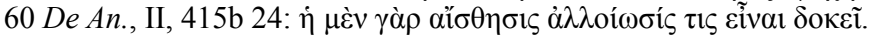

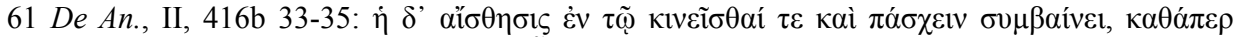

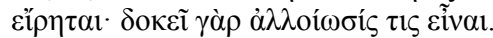

62 Averróis, in De An., II, comm. 51, p. 208, 13-19: Idest, dicamus igitur quod sentire fit per aliquam passionem et motum in sensibus a sensibilibus, non per actionem sensuum in sensibilia; hoc enim est primum consideratum de sensu, scilicet utrum sit numeratus in virtutibus activis aut passivis. Et cum posuit ipsum in genere virtutum passivarum, dedit causam istius existimationis.

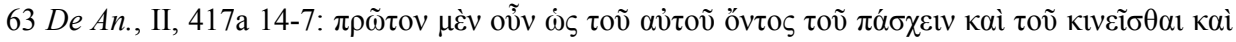

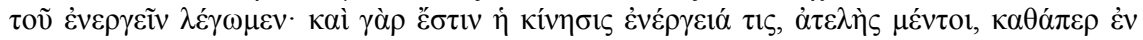

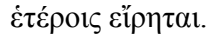

64 Aristóteles menciona um segundo objeto, para o qual o grego não tem um nome. RODIER (1985, p. 269): "Il s'agit des choses quine sont visibles que dans l'obscurité." Trata-se, portanto, da fosforescência. Averróis, in De An., II, comm. 66, p. 229, 11-12: "Et visibile est color, et sibi simile ex rebus que videntur in obscuro". Sto. Tomás menciona como exemplos noctilucae, seres que brilham durante a escuridão da noite (pirilampos e congêneres) e a putrefação dos carvalhos, que indicaria, na verdade, a presença de fungos bioluminescentes (in De An., II, 1. 14, n. 1): "quod quidem visibile competit his quae videntur de nocte, sicut sunt noctilucae, et putredines quercuum, et huiusmodi". Aristóteles trata um pouco mais disso em 419a 1-7.

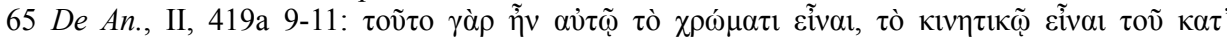

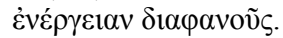

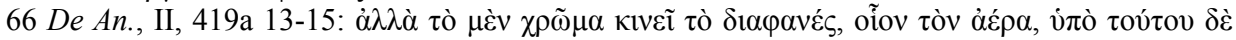

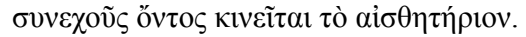

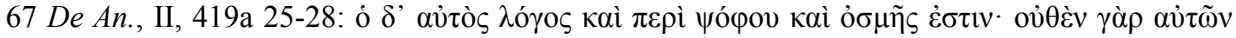

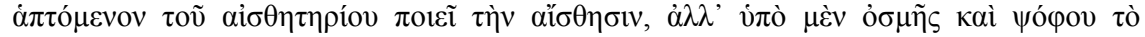

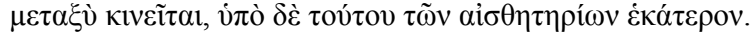

68 Cf. Met., A, 980a 23-27. Averróis, in De An., II, comm. 101, p. 284, 27-29: "Cum complevit sermonem de olfactu, et sensus gustus est illud quod debet consequi nunc secundum ordinem qui incipit a meliori et procedit ad magis necessarium, incepit loqui de eo et declarare quod est aliquis tactus..."

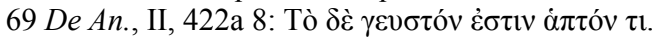

70 Sto. Tomás de Aquino, in De An., II, 1. 21, n. 2: "Et dicitur extraneum, quod non est pars animalis. Sentiuntur enim sensibilia, de quibus prius dictum est, per aerem aut aquam, quae non sunt partes animalis. Sed tactus non sentit suum obiectum per medium extraneum, sed per medium coniunctum. Nam caro est medium in sensu tactus, in infra patebit."

71 Cf. De An., II, 422b 34-423b 26.

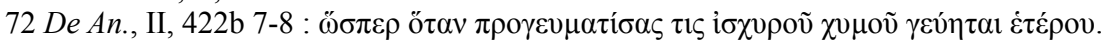

73 De An., II, 422b 2-3: "Com efeito, o gosto sofre uma certa ação da parte do objeto do gosto

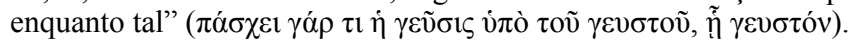

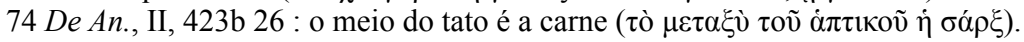

75 De An., II, 423b 2-3 : "conforme é a opinião atual que o gosto e o tato <funcionariam> por

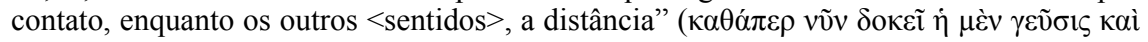

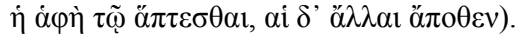

76 De An., II, 423b 12-15 : "Mas o tangível difere dos <objetos> visíveis e dos sonoros porque percebemos estes pelo fato de que o meio produz algo em nós, mas <percebemos> os

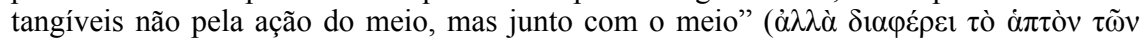

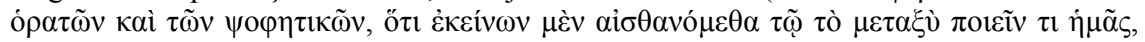

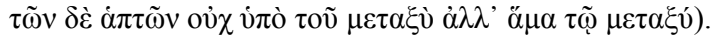

77 Averróis, in De An., II, comm. 121, p. 317, 15-17: "Si enim reciperet eas cum materia, tunc idem esse haberent in anima et extra animam". Sto. Tomás, comentando a mesma passagem, diz (in De An., II, 1. 24, n. 3): "Com efeito, ela (a forma), na coisa sensível, tem o ser natural, mas, no sentido, tem o ser intencional e espiritual”. (Nam in re sensibili 
habet esse naturale, in sensu autem habet esse intentionale et spirituale).

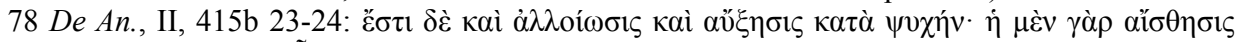

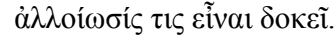

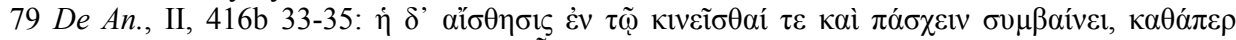

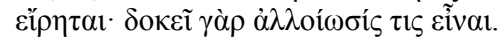

6680 Cf. Sto. Tomás de Aquino, in De An., II, 1. 11, n. 12. 